\title{
USPOREDBA MOGUĆNOSTI ZADAĆA (ASSIGNMENTS) U TEAMSU I EDMODU
}

\author{
Iva Naranda \\ II. osnovna škola Čakovec, Čakovec, Hrvatska
}

\begin{abstract}
Sažetak
U radu će se usporediti mogućnosti Zadaća (Assignments) u MS Teamsu i Edmodu, gledano s pozicije učitelja i učenika. Predstaviti će se online istraživanje o primjeni mogućnosti Zadaća na nastavi informatike, kako tijekom nastave u školi, tako i za vrijeme nastave na daljinu koje se provelo u prosincu 2020. među učenicima šestih i sedmih razreda II. osnovne škole Čakovec kako bi se dobila povratna informacija o primjeni ovih mogućnosti, gledano od strane učenika. Sudjelovanje u istraživanju bilo je anonimno, a provedeno je putem online upitnika kreiranog pomoću Google obrasca. Pitanja su se odnosila na nastavu informatike i primjenu Zadaća. Opcija Zadaća dostupna je učiteljima i učenicima kako bi se na jednom mjestu objedinile sve aktivnosti povezane s nekim zadatkom i kako bi se omogućilo jednostavno praćenje napretka učenika, davanje povratnih informacija učenicima i vođenje statistike za cijeli razred i svakog pojedinog učenika. Višegodišnje iskustvo u nastavi s obrazovnom mrežom Edmodo i nešto kraće iskustvo u radu s aplikacijom Teams, omogućilo je uočavanje nekih razlika, prednosti i nedostataka. Budući da je trenutna generacija učenika koristila Edmodo i Teams, pojavila se ideja da se provede istraživanje kako bi se dobio uvid u to kako učenici doživljavaju rad s Zadaćama na Edmodu i Teamsu. U ovom radu opisuje se provedeno istraživanje, predstavlja analiza rezultata i prikazuju se zaključci do kojih je dovelo istraživanje. Uz to, rad sadržava usporedbu mogućnosti Zadaća na Edmodu i Teamsu gledano s pozicije učitelja.
\end{abstract}

\section{Ključne riječi}

edukacija, informatika, osnovna škola, Edmodo, Teams, Zadaća

\section{Uvod}

Rad s Zadaćama (Assignments) koristio se tijekom nastave informatike još prije nastave na daljinu, što je bila prednost kada se zbog iznenadnog prelaska na nastavu na daljinu trebalo prebaciti na novi i drugačiji način izvođenja nastave. Kako se za nastavu Informatike još od školske godine 2014./2015. koristila obrazovna mreža Edmodo, nastavili smo rad u virtualnoj učionici na Edmodu i uslijed prelaska na nastavu na daljinu u ožujku 2020. godine. Početkom školske godine 2020./2021. počeli smo za nastavu Informatike koristiti aplikaciju MS Teams, komunikacijski i kolaboracijski alat $\mathrm{u}$ sklopu alata Office 365. Ovo je omogućilo učenicima stjecanje iskustva rada na još jednom online sustavu za organizaciju i provođenje nastave na daljinu. Ujedno, ovo je prilika da se s vremenom napravi sveobuhvatnija usporedba mogućnosti Edmoda i Teamsa za primjenu u nastavi. Za prijavu na Edmodo i Teams učenici i učitelji koriste AAI@EduHr elektroničke identitete. Za ovo istraživanje odabrana je mogućnost rada s Zadaćama iz razloga što je to $u$ nastavi Informatike bilo najviše korišteno tijekom školskih godina 2019./2020. i 2020./2021. Učenici su koristili Edmodo i Teams za vrijeme nastave u školi, ali i tijekom nastave na daljinu. 


\section{Glavni dio}

U školskoj godini 2020./2021. redovnu nastavu Informatike $\mathrm{u}$ šestom razredu polazi 66 učenika, a izbornu nastavu Informatike polazi 32 učenika. Online upitnik ispunilo je 58 učenika $(87,88 \%)$ šestog razreda i 25 učenika $(78,13 \%)$ sedmog razreda. Online upitnik sastojao se od 15 pitanja s ponuđenim odgovorima, od čega je prvo pitanje bilo odabir razreda.

Pri analizi rezultata treba imati na umu dvije činjenice. Prva je da su učenici s raznih uređaja i na razne načine pristupali Edmodu i Teamsu, što može utjecati na njihove odgovore, odnosno zadovoljstvo ili nezadovoljstvo pojedinom platformom. Drugo, što je također potrebno napomenuti je da su učenici u ožujku 2020. na nastavu na daljinu putem Edmoda ušli iznenada,

2) Koji uređaj si koristio za rad na Teamsu i Edmodu? (ako si koristio više uređaja, možeš odabrati više odgovora)

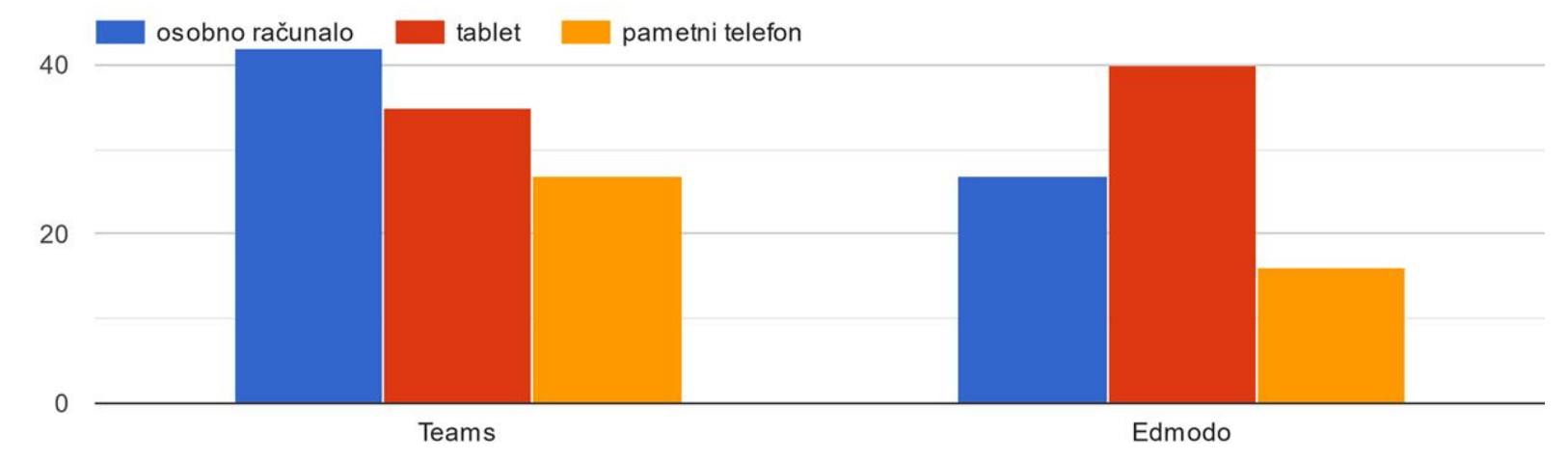

Grafikon 1: Korišteni uređaji, 6. razred bez posebne pripreme, dok su na početku školske godine 2020./2021. dobili upute za rad u Teamsu u svim okolnostima.

Sadašnji šesti razredi školske godine 2019./2020. opskrbljeni su tabletima iz projekta Škola za život te ih je veći broj učenika koristio tijekom nastave na daljinu u proljeće 2020. kada se za nastavu Informatike koristio Edmodo, dok su sadašnji sedmi razredi tablete dobili tek početkom školske godine 2020./2021. kada je za nastavu Informatike korišten Teams. Iznenađuje velik broj učenika koji je koristio pametne telefone za nastavu, naročito u školskoj godini 2020./2021. kada su svi učenici opskrbljeni tabletima, a radilo se na Teamsu. 
2) Koji uređaj si koristio za rad na Teamsu i Edmodu? (ako si koristio više uređaja, možeš odabrati više odgovora)

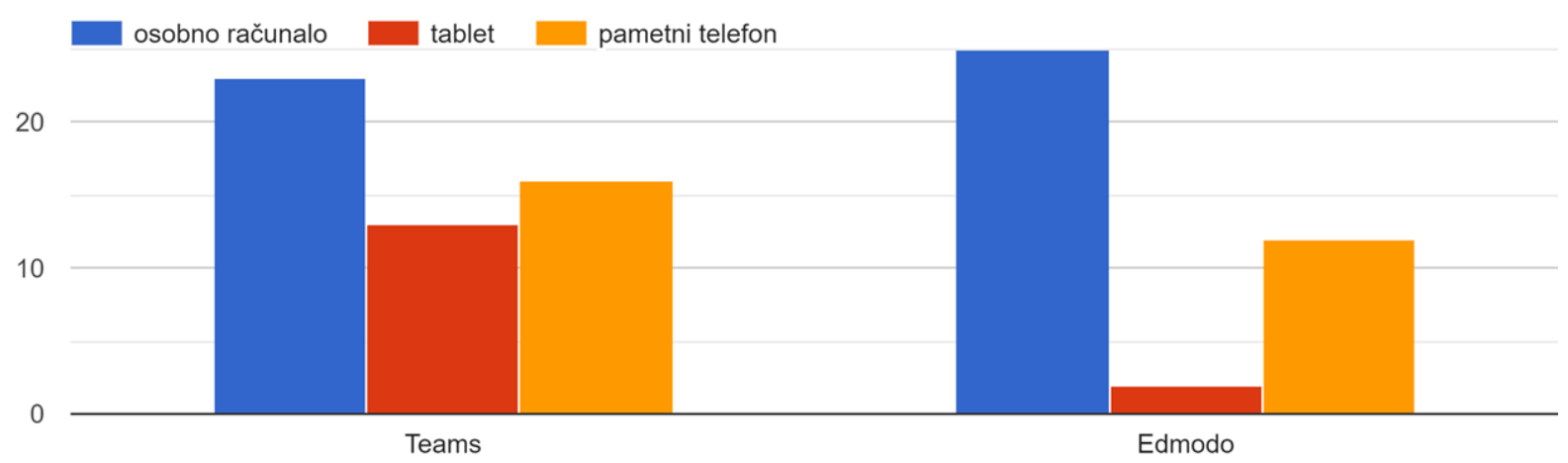

Grafikon 2: Korišteni uređaji, 7. razred

Razlikovao se i način pristupanja Edmodu i Teamsu. $44,8 \%$ učenika šestog razreda odgovorilo je da je Edmodu pristupalo direktno, 22,4\% učenika šestog razreda Edmodu je pristupalo preko sustava Office 365 , dok je $32,8 \%$ učenika šestog razreda koristilo oba načina. Teamsu je 56,9 \% učenika šestog razreda pristupalo direktno, 10,3 \% učenika šestog razreda Teamsu je pristupalo preko sustava Office 365 , dok je 32,8 $\%$ učenika šestog razreda koristilo oba načina. Za način pristupanja Edmodu 44 \% učenika sedmog razreda odgovorilo je da je Edmodu pristupalo direktno, $40 \%$ učenika sedmog razreda Edmodu je pristupalo preko sustava Office 365, dok je $16 \%$ učenika sedmog razreda koristilo oba načina. Teamsu je $56 \%$ učenika sedmog razreda pristupalo direktno, $24 \%$ učenika sedmog razreda Teamsu je pristupalo preko sustava Office 365, dok je $20 \%$ učenika sedmog razreda koristilo oba načina.

\section{Rad s Zadaćama}

Jedno od pitanja odnosilo se na zahtjevnost same predaje Zadaće. Tek manji broj učenika šestog razreda odgovorio je da je predaja Zadaće prilično komplicirana, a niti jednom učeniku šestog razreda predaja zadaće nije bila izuzetno komplicirana. Iako bi se moglo očekivati da će se stariji učenici lakše snaći, prema odgovorima učenika sedmog razreda može se zaključiti da je njima predaja Zadaće na Edmodu bila nešto kompliciranija što se djelomično može objasniti činjenicom da su u nastavu na daljinu preko Edmoda ušli iznenada i bez posebne pripreme. Iako su Edmodo koristili na nastavi u školi, prilikom samostalnog korištenja od kuće teže su se snalazili. 
5) Koliko zahtjevna ti je predaja Zadaće (Assignmentsa) na Teamsu ili Edmodu?

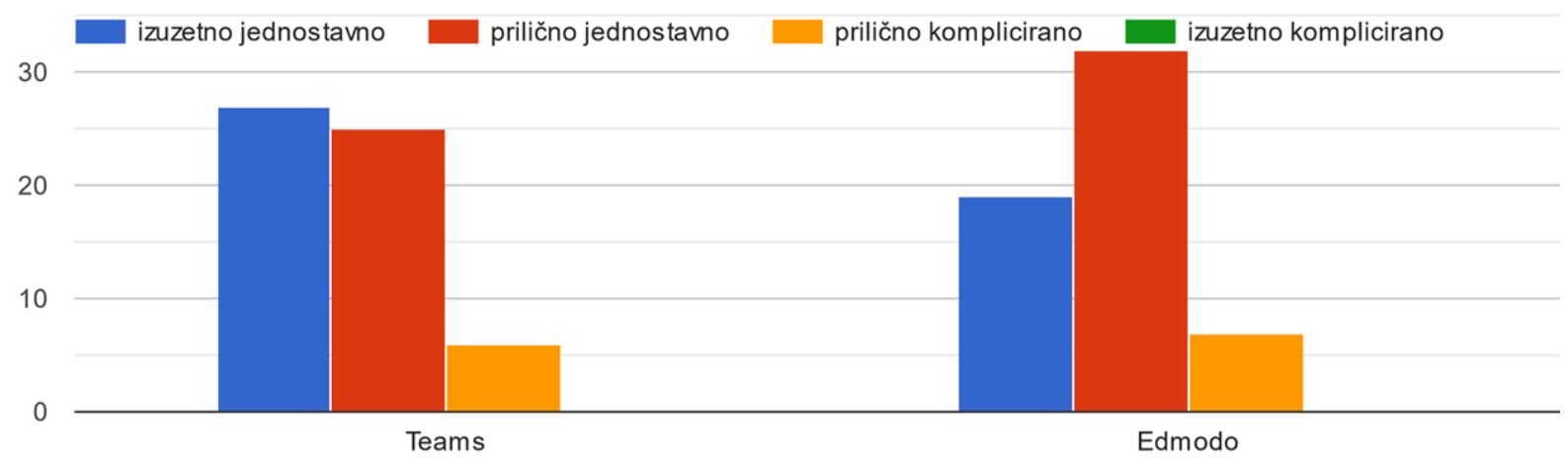

Grafikon 3: Predaja Zadaće, 6. razred

5) Koliko zahtjevna ti je predaja Zadaće (Assignmentsa) na Teamsu ili Edmodu?

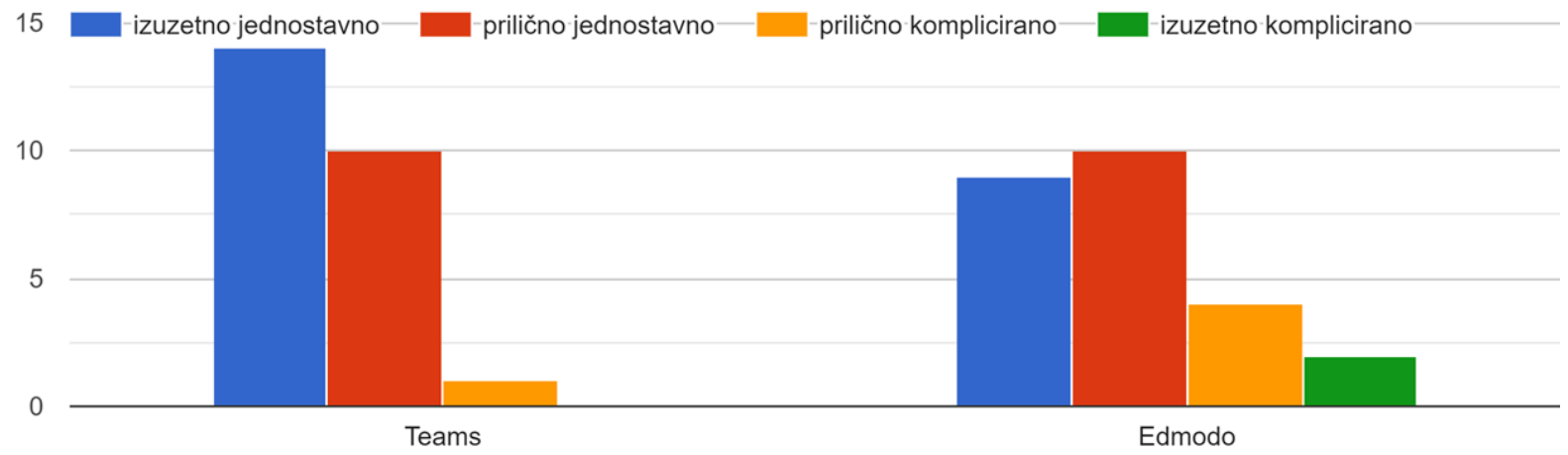

Grafikon 4: Predaja Zadaće, 7. razred

Istraživanjem se željelo dobiti povratnu informaciju od učenika o korisnosti komentara koje učenici mogu napisati uz predanu Zadaću, a što je omogućeno na Edmodu. Mnogi učenici su tijekom nastave na daljinu prilikom predaje svojih radova učiteljici napisali komentare, uglavnom vezane za korištenu opremu i inačice programa u kojima su radili, što je najčešće bilo objašnjenje zašto je nešto napravljeno, a nešto nije. Mogućnost Edmoda da učenici šalju svoj ko- mentar neposredno uz predaju Zadaće pokazala se korisnom u radu i olakšava praćenje rada učenika. Na Teamsu učenici komentare za svoje Zadaće mogu poslati učiteljici putem Čavrljanja (Chat) ili kao odgovor na Zadaću koji vide svi članovi tima kojima je dostupna određena Zadaća (najčešće cijeli razred). Obje opcije nisu spretne u radu, poruka u Čavrljanju nije direktno povezana s određenom Zadaćom, dok odgovor koji vide i drugi učenici nije uvijek prikladno rješenje. 
6) Jesi li koristio mogućnost slanja komentara uz predanu zadaću na Edmodu? 58 odgovora

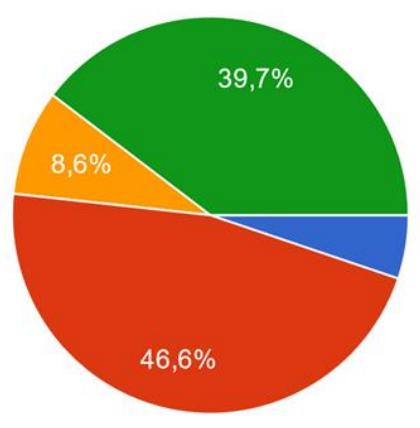

$\mathrm{Da}$, često

$\mathrm{Da}$, ponekad.

$\mathrm{Ne}$.

Ne sjećam se.

Grafikon 5: Slanje komentara uz predanu Zadaću, 6. razred

6) Jesi li koristio mogućnost slanja komentara uz predanu zadaću na Edmodu? 25 odgovora

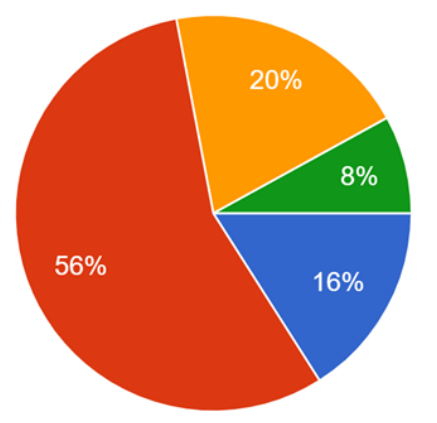

Da, često.

Da, ponekad.

Ne.

Ne sjećam se.

Grafikon 6: Slanje komentara uz predanu Zadaću, 7. razred

7) Nedostaje li ti mogućnost pisanja komentara uz predaju zadaće na Teamsu? 58 odgovora

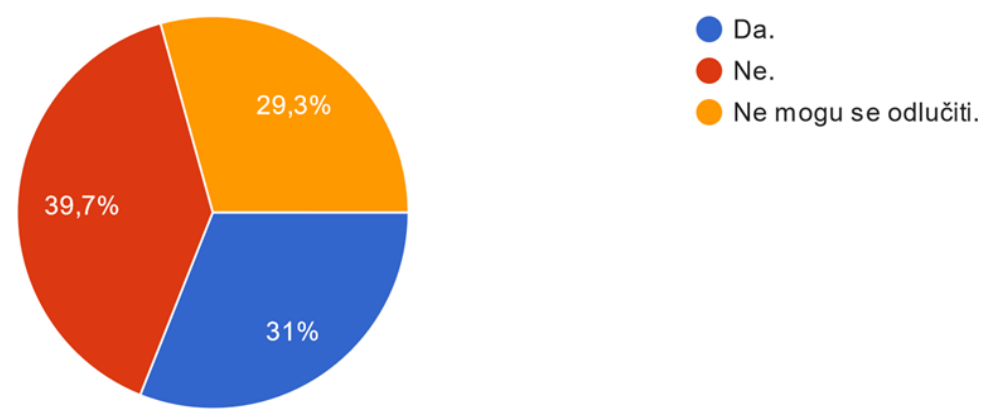

Grafikon 7: Pisanje komentara uz predanu Zadaću, 6. razred 
7) Nedostaje li ti mogućnost pisanja komentara uz predaju zadaće na Teamsu?

25 odgovora

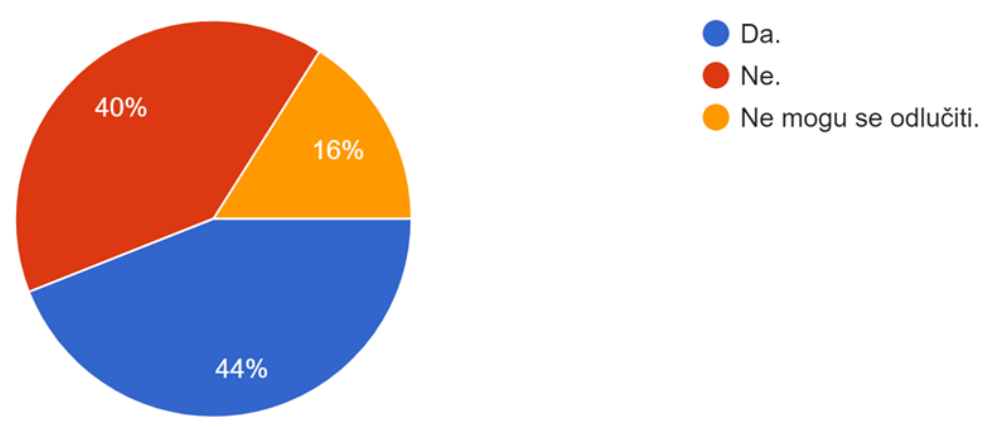

Grafikon 8: Pisanje komentara uz predanu Zadaću, 7. razred

9) Jesu li ti povratne informacije od učiteljice bile dovoljno jasne kako bi mogao napraviti tražene ispravke i ponovo predati svoj rad?

58 odgovora

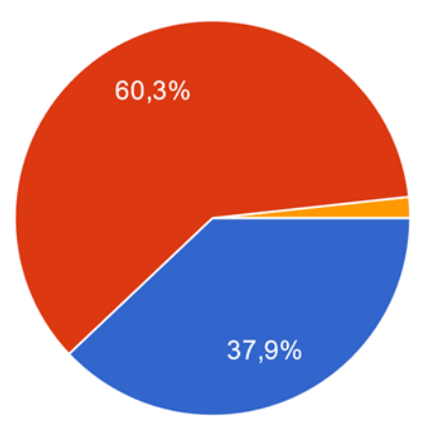

Da, uvijek.

Uglannom da.

Ne.

Nisam čitao komentare učiteljice.

Grafikon 9: Povratne informacije, 6. razred

9) Jesu li ti povratne informacije od učiteljice bile dovoljno jasne kako bi mogao napraviti tražene ispravke i ponovo predati svoj rad?

25 odgovora

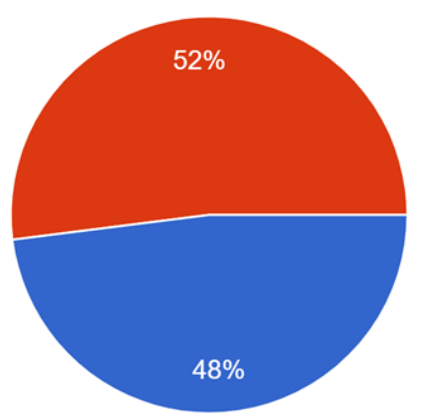

Da, uvijek.

Uglavnom da.

$\mathrm{Ne}$.

Nisam čitao komentare učiteljice.

Grafikon 10: Povratne informacije, 7. razred 
Opcija Zadaća omogućuje da se na jednom mjestu objedine sve aktivnosti povezane s nekim zadatkom, realizira komunikacija učenika i učitelja, dokumentira rad i prati napredak učenika. Prednost je što se sve aktivnosti (npr. kada je zadan zadatak, kada je predan učenički rad, je li rad vraćen učeniku na doradu i kada, eventualna predaja ispravljenog učeničkog rada i drugo) evidentiraju s datumom i vremenom, što omogućuje rješavanje eventualnih nesuglasica oko izvršavanja obaveza u zadanim rokovima, kako za učenike, tako i za učitelje. Ipak, uočeni su neki detalji koji mogu znatno utjecati na rad. U praksi se ponekad događa da učenik iz nekog razloga nije u mogućnosti predati svoj rad u Zadaći te svoj rad pošalje učiteljici nekim drugim komunikacijskim kanalom, npr. kao privitak u privatnoj poruci, putem emaila i slično. U tom slučaju, kako bi ipak sve bilo objedinjeno na jednom mjestu, na Edmodu učitelj može koristiti mogućnost da se uz slanje komentara priloži datoteka, u ovom slučaju učenički rad koji je predan nekim drugim komunikacijskim kanalom. Na Teamsu se uz predani rad može napisati komentar, ali bez prilaganja datoteke, što nije rješenje za ranije opisanu situaciju. Mogućnost prilaganja datoteke uz komentar u Zadaći može dobro doći i u drugim situacijama, primjerice kada je učeniku potrebna dodatna uputa (npr. snimka zaslona) za neki specifični problem koji je javio.

Još jedan detalj uočen u praksi vezan je uz bilježenje datuma i vremena predaje komentara (povratne informacije) učeniku. Na Edmodu je svaki komentar evidentiran s datumom i vremenom, dok se na Teamsu eventualne dodatne povratne informacije bilježe kao nastavak prve, bez posebnog datuma, što je nepregledno i može biti zbunjujuće. Na Teamsu problem može izazvati mogućnost da učenik naknadno obriše ili izmijeni svoj rad koji je predao, bez da se sačuva prva verzija predanog rada. $U$ tom slučaju komentari učitelja mogu biti neprikladni i neaktualni, a cjelokupan slijed rada učenika nije zabilježen.

Gledano s pozicije učitelja koji ima uvid u statistiku cijelog razreda, uočena je prednost Edmoda koju predstavlja brojčani prikaz predanih učeničkih radova, ocijenjenih, neocijenjenih i nepredanih radova. Teams brojčano prikazuje radove vraćene na doradu, ali ne prikazuje broj ocijenjenih i neocijenjenih radova.

\section{Rad s kvizovima}

Teams i Edmodo imaju mogućnost uporabe kvizova koji automatski bilježe bodove u statistici, za pojedinog učenika i za cijeli razred. Teams je povezan s MS Formsom te se $\mathrm{u}$ Zadaćama vrlo jednostavno mogu koristiti kvizovi koje učitelj ima na Formsu, bilo vlastiti ili duplicirani (npr. kvizovi dostupni u materijalima za učitelje uz udžbenike). U Edmodu ima mogućnost kreiranja vlastitih kvizova. Prema odgovorima učenika može se zaključiti da je najveći broj učenika zadovoljan s mogućnostima kvizova na Teamsu i Edmodu. Učiteljima Edmodo pruža veću preglednost rezultata $u$ vidu grafičkog prikaza rezultata za svako pitanje, po učeniku i za cijeli razred, prikaz učenika s najboljim rezultatom i više statističkih podataka. 
10) Kvizovi na Teamsu i Edmodu su:

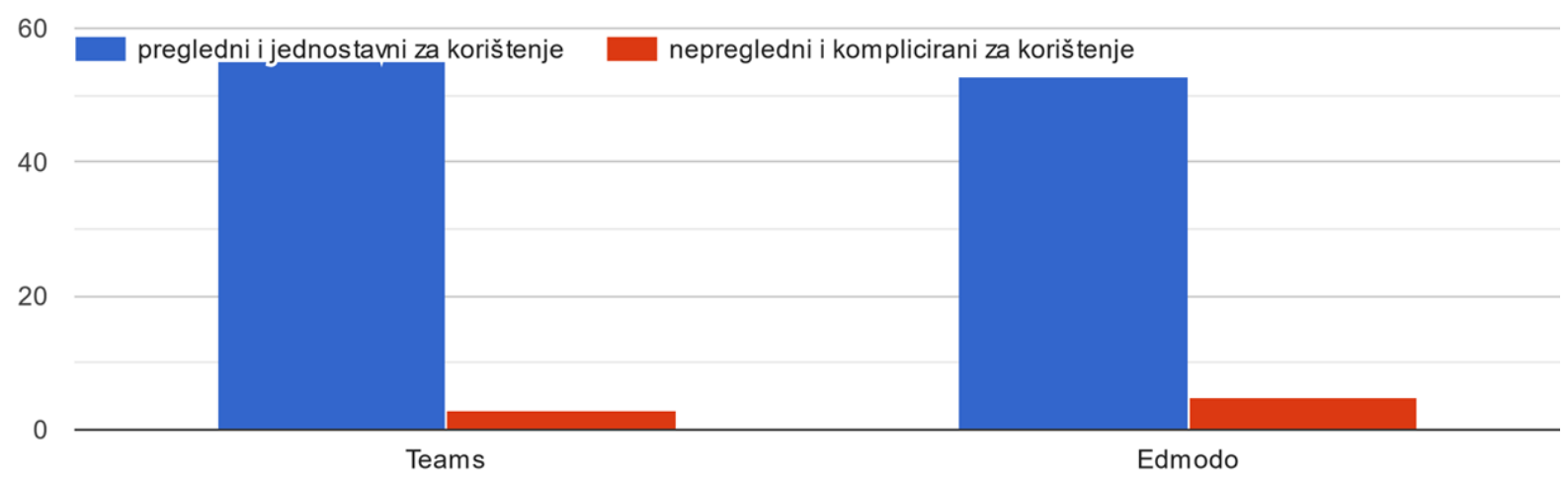

Grafikon 11: Kvizovi, 6. razred

10) Kvizovi na Teamsu i Edmodu su:

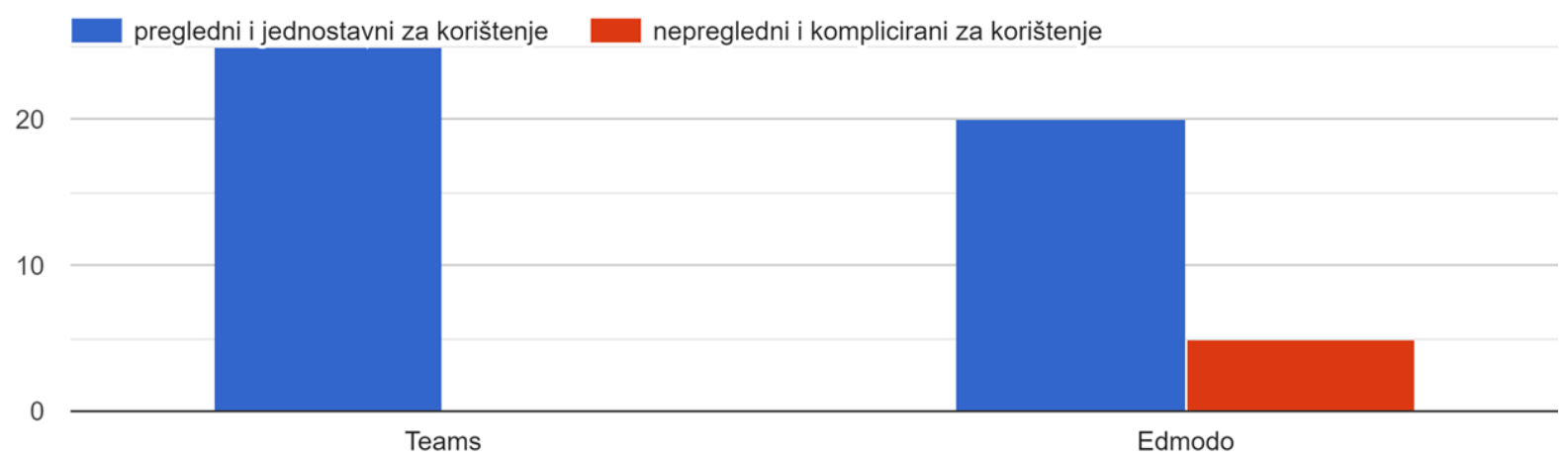

Grafikon 12: Kvizovi, 7. razred

\section{Uključenost roditelja}

Roditelji također trebaju pratiti aktivnosti svoje djece, a ovdje dolazimo do značajne razlike između Edmoda i Teamsa. Edmodo pruža mogućnost da se roditelji pridruže i između ostaloga direktno dobivaju obavijesti o aktivnostima, zadaćama i rokovima. Iako je u II. osnovnoj školi Čakovec tek manji broj roditelja koristio Edmodo, smatram da ova mogućnost predstavlja izvrsno rješenje za komunikaciju s roditeljima. U Teamsu roditelji mogu pratiti rad svoje djece ako se prijave s učeničkim korisničkim računom svojeg djeteta i nemaju mogućnost direktne komunikacije s učiteljem. Prijava i korištenje aplikacije Teams za nastavu na daljinu iz sigurnosnih razloga je ograničena na korisnike koji posjeduju račun @skole.hr, što ne obuhvaća roditelje. Za komunikaciju s roditeljima potrebno je uspostavljanje nekog drugog kanala komunikacije, no u tom slučaju roditelji neće dobivati automatske obavijesti o aktivnostima na Teamsu.

\section{Zaključak}

Kako bi se učenicima omogućilo kvalitetno obrazovanje između ostaloga danas je u procesu učenja i poučavanja koji se većim ili manjim dijelom odvija u virtualnom okruženju uz podršku digitalnih tehnologija potrebno koristiti razne komunikacijske kanale i aplikacije. Procjena kvalitete i funkcionalnosti pojedine aplikacije može se razlikovati ovisno o tome promatramo li aplikaciju kao učenik ili kao učitelj. Ono 
što jednima odgovara, ne mora nužno odgovarati i drugima. Učiteljima općenito više odgovara veća mogućnost upravljanja radom razreda i automatsko bilježenje svih aktivnosti, a upravo to nekim učenicima može manje odgovarati. Generalno gledano, opcija Zadaća izuzetno je korisna mogućnost koja olakšava rad učiteljima i učenicima te pruža mogućnost praćenja napretka pojedinog učenika i cijelog razreda. Razlike su u detaljima što bolje mogu primijetiti i usporediti učitelji. Iz dosadašnjeg iskustva i uočenih razlika između Edmoda i Teamsa u radu s Zadaćama, može se zaključiti da Edmodo nudi više i da je bolje prilagođen potrebama škola i radu u nastavi. Moguće je da neki učenici, ali i učitelji, uopće ne koriste neke od ponuđenih mogućnosti u radu s Zadaćama, što može negativno utjecati na njihovu procjenu korisnosti primjene Zadaća u nastavi. U praksi nije korišten MS Teams dodatak Insights koji učiteljima omogućuje napredno praćenje aktivnosti učenika. Također, postoje manje razlike $\mathrm{u}$ funkcionalnostima aplikacija ovisno o korištenom uređaju, o tome koristi li se aplikacija preuzeta na računalo ili web aplikacija, a ponekad i o korištenom mrežnom pregledniku. Sve ovo može utjecati na dojam korisnika o pojedinoj aplikaciji, kako učenika, tako i učitelja. Sustavi i aplikacije neprestano se poboljšavaju i nadograđuju novim mogućnostima zbog čega je potrebno kontinuirano usavršavanje učitelja kako bi se novosti mogle implementirati u procesu poučavanja $\mathrm{u}$ razredu i virtualnim učionicama.

\section{Literatura}

1. Carol C. Kuhlthau, Leslie K. Maniotes, Ann K. Caspari, Vođeno istraživačko učenje učenje u 21. stoljeću, Školska knjiga, Zagreb 2019.

2. CARNet, ICT Edu - modul 5: Suradničko učenje i Edmodo, 2009.

3. Edmodo Help Center, Using Edmodo, Assignments, https://support.edmodo.com/hc/en$\underline{\text { us/categories/200328890 , datum pristupa }}$ 1.12.2020.

4. Microsoft Teams help and learning, https://support.microsoft.com/en-us/teams , datum pristupa 1.12.2020.

\title{
COMPARISON OF ASSIGNMENTS IN TEAMS AND EDMODO
}

\author{
Iva Naranda \\ II. Elementary School Čakovec, Čakovec, Croatia
}

\begin{abstract}
The paper will compare the possibilities of Assignments in MS Teams and Edmodo, viewed from the position of teachers and students. An online research on the application of the Possibilities task will be presented in the teaching of informatics, both during school teaching and during distance learning, which was conducted in December 2020 among sixth and seventh grade II students. elementary school Čakovec in order to get feedback on the application of these possibilities, seen by students. Participation in the survey was anonymous and was conducted through an online questionnaire created using a Google form. The questions were related to the teaching of informatics and the application of the Tasks. The Task option is available to teachers and students to bring together all the activities related to a task in one place and to allow easy monitoring of student progress, giving feedback to students and keeping statistics for the whole class and each individual student. Many years of teaching experience with the Edmodo educational network and a somewhat shorter experience working with the Teams application, made it possible to notice some differences, advantages and disadvantages. Because the current generation of students used Edmodo and Teams, the idea arose to conduct research to gain insight into how
\end{abstract}


students experience working with Tasks on Edmodo and Teams. This paper describes the conducted research, presents an analysis of the results and presents the conclusions reached by the research. In addition, working with-states compares the task assignments on Edmod and Teams viewed from a teacher's position.

Keywords

education, informatics, elementary school, Edmodo, Teams, Homework 